\title{
HUBUNGAN KONSUMSI FE TERHADAP KEJADIAN ANEMIA PADA IBU HAMIL DI KABUPATEN KARAWANG TAHUN 2014
}

\author{
RELATIONSHIP OF FE CONSUMPTION TO ANEMIA IN PREGNANT WOMEN IN \\ KABUPATEN KARAWANG YEAR 2014
}

\author{
Jundra Darwanty \\ Prodi Kebidanan Karawang, Poltekkes Kemenkes Bandung \\ Email : djundra@yahoo.com
}

\begin{abstract}
ABSTRAK
Menurut United Nation yang dikutip oleh Soegianto (1993), tingginya prevalensi anemia pada kehamilan melatarbelakangi terjadinya kematian ibu sewaktu hamil. Hasil riskesdas tahun 2013 ditemukan angka kejadian anemia pada kelompok ibu hamil sebesar 37,1\%. Di Jawa barat angka kejadian anemia 40-43\%, sedangkan angka kejadian anemia pada ibu hamil yang ada di Kabupaten Karawang adalah sebesar 45\%. Hasil studi pendahuluan di Puskesmas Tanjung pura ditemukan $40 \%$ ibu hamil dengan anemia, sedagkan cakupan pemberian FE pada ibu hamil mencapai 87,6\%. Menurut penelitian yang dilakukan oleh Hoo Swie Tjiong di Rumah Sakit (RS) Dr. Cipto Mangunkusumo, frekuensi anemia dalam kehamilan banyak 18,5\%, Pseudonemia 57,9\% dan wanita hamil dengan $\mathrm{Hb} 12 \mathrm{gr} \%$ atau lebih sebanyak 23,6\%. Penelitian ini bertujuan untuk mengetahui bagaimana hubungan antara konsumsi FE dengan kejadian anemia pada kehamilan di kabupaten karawang. Desain penelitin ini adalah metode penelititan deskriptif analitik. Dengan pendekatan crossecsional. Teknik pengambilan sampel yang dilakukan adalah dengan teknik simple rondom sampling pada ibu-ibu hamil trimester di tiga puskesmas, Dengklok, Pedes, Karawang Kota dan Purwasari Kabupaten Karawang, dengan jumlah sampel 111. Analisa univariat dan bivariat menggunakan uji statistik uji Chi Square dengan derajat kemaknaan 95\%. Ada hubungan kejadian anemia dengan Jumlah Fe yang dikonsumsi ibu selama hamil.
\end{abstract}

Kata Kunci: Fe, Ibu Hamil, Anemia

\section{ABTRACT}

According to United Nation, cited by Soegianto (1993), the high prevalence of anemia in pregnancy lies in the occurrence of maternal mortality during pregnancy. The result of riskesdas in 2013 found the incidence of anemia in the group of pregnant women by $37.1 \%$. In West Java the incidence rate of anemia is 40-43\%. While the incidence rate of anemia in pregnant women in Karawang regency is 45\%. The results of preliminary study in Puskesmas Tanjung Pura found $40 \%$ of pregnant women with anemia, while coverage of FE in pregnant women reached $87.6 \%$. According to research conducted by Hoo Swie Tjiong at the Dr. Cipto Mangunkusumo hospital, the frequency of anemia in pregnancy is $18.5 \%$, Pseudonemia $57.9 \%$ and pregnant women with $\mathrm{Hb} 12 \mathrm{gr} \%$ or more as much as $23.6 \%$. This study aims to determine how the relationship between consumption of FE in pregnant women with anemia prevalence in pregnancy in karawang regency. The design of this research is analytical descriptive research method. With crossecsional approach. The sampling technique is done by simple random sampling technique on trimester pregnant women of three puskesmas, Dengklok, Pedes, Karawang city and Purwasari of Karawang regency, with total sample 111. Univariate and bivariate analysis using statistical test of Chi Square test with degree of significance $95 \%$. There is relationship between consumption of FE in pregnant women with anemia prevalence

Keywords: Fe, Pregnant Mother, Anemia

\section{PENDAHULUAN}

Menurut United Nation yang dikutip oleh Soegianto (1993), tingginya prevalensi anemia pada kehamilan melatarbelakangi terjadinya kematian ibu sewaktu hamil, bersalin atau nifas sebagai akibat komplikasi penanganannya. Disamping dapat mengakibatkan kematian, anemia defisiensi besi pada kehamilan menyebabkan pertumbuhan janin dalam kandungan terganggu, dan munculnya Berat Bayi Lahir Rendah (BBLR) 
Hasil riskesdas tahun 2013 ditemukan angka kejadian amenia pada kelompok ibu hamil adalah sebesar 37,1 dengan proporsi yang hampir sama pada bumil di perkotaan $(36,4 \%)$ dan perdesaan $(37,8 \%)$. Jawa barat 40-43\%. Di Puskesmas Bogor Tengah prevalensi anemia pada ibu hamil yaitu $63,63 \%$.

Sedangkan angka kejadian anemia pada ibu hamil yang ada di Kabupaten Karawang adalah sebesar 45\% (Dinkes Kab. Karawang, 2015). Hasil studi pendahuluan yang penulis lakukan ditemukan $40 \%$ ibu hamil dengan anemia (Kelurahan Tanjungpura, 2015)

Menurut penelitian yang dilakukan oleh Hoo Swie Tjiong di Rumah Sakit (RS), diketahui bahawa frekuensi anemia dalam kehamilan banyak 18,5\%, Pseudonemia $57,9 \%$ dan wanita hamil dengan $\mathrm{Hb} 12 \mathrm{gr} \%$ atau lebih sebanyak $23,6 \%$, Hb rata-rata 12,3 gr\% pada trimester satu, 11,3 gr\% pada trimester dua dan 10,8 gr\% pada trimester tiga. Hal ini disebabkan karena pengenceran darah semakin nyata dengan lanjutnya usia kehamilan sehingga frekuensi anemia dalam kehamilan meningkat pula (Wikndjodastro,2005).

Penyebab terbesar terjadinya anemia dalam kehamilan adalah defisiensi FE, sehingga World Health Organization (1968) menganjurkan untuk memberikan suplementasi Fe kepada ibu hamil, karena keperluan zat besi pada masa hamil tidak dapat dipenuhi hanya dari makan saja. Ibu hamil sangat disarankan untuk minum tablet besi sebanyak 90 tablet yang harus diminum setiap hari. Suatu penelitian menunjukan bahwa wanita hamil yang tidak minum pil besi mengalami penurunan ferritin (cadangan besi) cukup tajam sejak minggu ke 12 usia kehamilan (Khomsan, 2003). Penelitian lain yang dilakukan Nurhayati (2014) ada pengaruh pembeian FE terhadap kejadian anemia pada ibu hamil

\section{METODE PENELITIAN}

Penelitian ini adalah penelitian deskriptif analitik dengan metode pendekatan secara crossectional. Penelitian ini dilaksanakan di Wilayah Dinas Kesehatan Kabupaten Karawang pada tahun 2014. Yang menjadi populasi penelitian ini adalah seluruh ibu hamil yang datang berkunjung pada puskesmas di Kabupaten Karawang Juli sampai September 2014. Teknik pengambilan sampel yang dilakukan adalah dengan teknik simple random sampling pada ibu-ibu hamil trimester tiga Puskesmas, Dengklok, Pedes, Karawang kota dan Purwasari Kabupaten Karawang, dengan jumlah sampel 112. Dalam pengamblan sampel 1 responden tidak dapat diolah. Teknik analisa data menggunakan analisa univariat dan bivariat dengan menggunakan uji chi square.

Analisa data meliputi analisa univariat dan bivariat menggunakan uji statistik uji Chi Square dengan derajat kemaknaan 95\%. Penelitian ini bertujuan Mengetahui bagaimana hubungan pemberian Fe pada ibu hamil terhadap kejadian anemia.

\section{HASIL DAN PEMAHASAN}

Tabel 4.1 Distribusi Frekuensi Ibu Hamil berdasarkan kejadian Anemia di Kabupaten Karawang tahun 2014.

\begin{tabular}{|l|l|l|}
\hline Kejadian anemia & Jumlah & Persentasi \\
\hline Anemia & 49 & 44.1 \\
\hline Tidak anemia & 62 & 55.9 \\
\hline Jumlah & 111 & 100 \\
\hline
\end{tabular}

Dari tabel di atas diketahui bahwa jumlah ibu hamil yang anemia lebih sedikit dibandingkan dengan yang tidak anemia.

Tabel 4.2 Distribusi Frekuensi Jumlah Konsumsi tablet Fe Pada Ibu Hamil di Kabupaten Karawang tahun 2014.

\begin{tabular}{|l|l|l|}
\hline $\begin{array}{l}\text { Jumlah Fe yang } \\
\text { dikonsumsi ibu }\end{array}$ & Jumlah & Persentasi \\
\hline$<90$ tablet & 34 & 30,6 \\
\hline$\geq 90$ tablet & 77 & 69.4 \\
\hline
\end{tabular}




\begin{tabular}{|l|l|l|}
\hline Jumlah & 111 & 100 \\
\hline Data di atas menunjukkan bahwa
\end{tabular}
cakupan pemberian tablet fe yang mencapai 90 tablet selama kehamilan dua kali lebih banyak dibandingkan dengan yang kurang dari 90 tablet

Tabel 4.3 Distribusi Frekuensi Rutinitas Konsumsi Fe Pada Ibu hamil di Kabupaten Karawang tahun 2014.

\begin{tabular}{|l|l|l|}
\hline $\begin{array}{l}\text { Rutinitas } \\
\text { konsumsi Fe }\end{array}$ & Jumlah & Persentasi \\
\hline Rutin & 59 & 53,2 \\
\hline Tidak rutin & 52 & 46.8 \\
\hline Jumlah & 111 & 100 \\
\hline
\end{tabular}

Dari seluruh ibu hamil yang diberi $\mathrm{Fe}$ baru 53,2 persen yang mengkonsumsi 90 tablet Fe secara rutun setiap harinya. Hal ini menunjukan masih banyak ibu hamil yang mendapatkan $\mathrm{Fe}$ tetapi tidak dikonsumsi secara sesuai dengan anjuran.

Tabel 4.4 Distribusi Frekuensi Waktu Konsumsi Fe Pada Ibu hamil di Kabupaten Karawang tahun 2014.

\begin{tabular}{|l|l|l|}
\hline Waktu minum & Jumlah & Persentasi \\
\hline Malah hari & 94 & 84,7 \\
\hline Pagi hari & 17 & 15.3 \\
\hline Jumlah & 111 & 100 \\
\hline
\end{tabular}

Berdasarkan hasil oleh data yang penulis lakukan terlihat bahwa sebagian besar ibu hamil sudah menkonsumsi Fe pada malam hari, dan hanya sebagian kecil yang mengkonsumsi pada pagi hari

Tabel 4.5 Distribusi Frekuensi Ibu Hamil Mulai konsumsi Fe Di Kabupaten Karawang Tahun 2014

\begin{tabular}{|l|l|l|}
\hline Mulai konsumsi Fe & Jumlah & Persentasi \\
\hline Kehamilan $<12 \mathrm{mg}$ & 34 & 30,6 \\
\hline Kehamilan $\geq 12 \mathrm{mg}$ & 77 & 69.4 \\
\hline Jumlah & 111 & 100 \\
\hline
\end{tabular}

Konsumsi $\mathrm{Fe}$ pada sebagian besar responden dimulai setelah kehamilan 12 minggu dan hanya $30 \%$ yang mengkonsumsi sebelum kehamilan 12 Minggu

\section{Tabel 4.6 Hubungan Konsumsi Fe Pada Ibu Hamil Dengan Dengan kejadian Anemia Pada Ibu hamil di Kabupaten Karawang tahun 2014}

\begin{tabular}{|c|c|c|c|c|c|c|c|}
\hline \multirow{3}{*}{$\begin{array}{l}\text { Konsunsi } \\
\text { Fe ibu } \\
\text { hamil }\end{array}$} & \multicolumn{4}{|c|}{ Anemia } & \multirow{2}{*}{\multicolumn{2}{|c|}{ Jumlah }} & \multirow[t]{3}{*}{$\mathrm{P}$} \\
\hline & \multicolumn{2}{|c|}{$\mathrm{Ya}$} & \multicolumn{2}{|c|}{ Tidak } & & & \\
\hline & $\mathrm{F}$ & $\%$ & $f$ & $\%$ & $\mathrm{f}$ & $\%$ & \\
\hline $\begin{array}{l}\text { Jumlah } \\
\text { Konsumsi } \\
\mathrm{Fe}<\quad 90 \\
\text { tablet }\end{array}$ & 24 & 29,4 & 10 & 70,6 & 34 & 100 & 0.03 \\
\hline $\begin{array}{l}\text { Jumlah } \\
\text { Konsumsi } \\
\text { Fe } \geq 90 \\
\text { tablet }\end{array}$ & 38 & 49,4 & 39 & 50,6 & 77 & 100 & \\
\hline $\begin{array}{l}\text { Konsumsi } \\
\text { secara } \\
\text { Rutin }\end{array}$ & 33 & 55.9 & 26 & 44,1 & 59 & 100 & 0,98 \\
\hline $\begin{array}{l}\text { Konsumsi } \\
\text { Tidak } \\
\text { rutin }\end{array}$ & 29 & 55,8 & 23 & 42,2 & 77 & 100 & \\
\hline $\begin{array}{l}\text { Waktu } \\
\text { minum } \\
\text { Malam } \\
\text { hari }\end{array}$ & 53 & 56.4 & 41 & 43,6 & 94 & 100 & 0,79 \\
\hline $\begin{array}{l}\text { Waktu } \\
\text { minum } \\
\text { Pagi hari }\end{array}$ & 9 & 55,9 & 8 & 44,1 & 17 & 100 & \\
\hline $\begin{array}{l}\text { Mulai } \\
\text { konsumsi } \\
\text { pada } \\
\text { hamil < } \\
12 \\
\text { Minggu }\end{array}$ & 18 & 52,9 & 16 & 47,1 & 34 & 100 & 0,68 \\
\hline $\begin{array}{l}\text { Mulai } \\
\text { konsumsi } \\
\text { pada } \\
\text { hamil } \geq \\
12 \\
\text { minggu }\end{array}$ & 44 & 51,7 & 33 & 42,9 & 77 & 100 & \\
\hline
\end{tabular}

Berdasarkan uji statistik yang dilakukan, dari 4 variabel yang diteliti hanya jumlah konsumsi $\mathrm{Fe}$ yang mempunyai hubungan dengan kejadian anemia pada ibu hamil. Sedangkan rutinitas, waktu minum dan usia kehamilan saat mulai konsunsi fe tidak 
ditemukan adanya pengaruh terhadap kejadian anemia pada ibu hamil.

Dalam penelitian ini keterbatasan penulis data yang dgunakan adalah data primer, dengan mengunakan kuesioner, tanpa melakukan observasi. Selain itu data yang diambil tidak di kroscek dengan data dokumentasi yang ada. Karena tidak semua ibu Responden mempunyai buku KIA

\section{PEMBAHASAN}

\section{Hubungan Jumlah Konsumsi FE dengan kejadian Amenia pada Ibu Hamil.}

Anemia dalam kehamilan dapat membahayakan ibu dan janin. Anemia pada ibu dalam kehamilan dapat meningkatkan risiko terjadinya perdarahan postpartum. Anemia yang terjadi sejak awal kehamilan dapat menjadi penyebab persalinan prematur, terganggunya pertumbuhan janin sehingga dapat mengakibatkan penyakit kardiovaskular setelah bayi dewasa. Anemia pada kehamilan muda dapat dan dapat mempengaruhi sistim vaskularisasi plasenta.

Prevalensi Anemia Defisiensi Besi (ADB) bervariasi antar negara, bahkan antar wilayah, s angat bergantung pada pola nutrisi dan pola kesehatan masyarakat di wilayah tersebut. Secara umum prevalensi ADB relatif rendah pada trimester pertama dan kemudian meningkat pada trimester 2. Sekitar 50\% ADB terjadi setelah kehamilan 25 minggu.

Seefried (1995), yang mendapatkan bahwa prevalensi kekurangan simpanan besi di tubuh pada pasien-pasien di Rumah Sakit Universitas Zurich berkisar $35 \%$ sedangkan yang bermanifestasi sebagai ADB adalah 10\%.8 Dalam kehamilan terjadi perubahan hematologik yang mengakibatkan terjadinya anemia defisiensi besi. Pada kehamilan dengan satu janin kebutuhan ibu akan besi akibat kehamilan adalah sebesar $1000 \mathrm{mg}$. Sekitar $300 \mathrm{mg}$ untuk janin dan plasenta, $500 \mathrm{mg}$ untuk peningkatan massa hemoglobin dan sekitar $200 \quad \mathrm{mg}$ dikeluarkan melalui saluran cerna, urin dan kulit. Jumlah total $1000 \mathrm{mg}$ ini pada umumnya melebihi simpanan besi pada kebanyakan wanita. Jika kebutuhan ini tidak dapat dikompensasi dari peningkatan absorpsi besi,maka terjadilah anemia defisiensi besi.

Penelitian lain yang dilakukan nurhayati (2014) mendaptkan hasil bahwa sebagian responden mengalami peningkatan $\mathrm{Hb}$ setelah mengkonsumsi tablet $\mathrm{Fe}$

Hasil penelitian ini menunjukan bahwa jumlah Fe yang di konsumsi oleh ibu hamil selama kehamilan ada hubungannya dengan angka kejadian anemia dalam kehamilan. Hal ini dibuktikan dengan hasil analisa statistic yang didapatkan nilai $\mathrm{p}=0,03(\mathrm{p}=<0.05)$

Besi merupakan trace element yang terbanyak pada tubuh manusia dan merupakan salah satu elemen yang terbanyak di alam ini. Rata-rata kandungan besi pada manusia dewasa yang sehat berkisar antara 4-5 gram (40-50 mg Fe/kg berat badan). Besi terikat pada bagian globulin dari transferin secara longgar hingga dapat dibebaskan pada sel-sel jaringan pada setiap tempat pada tubuh. Besi transit melalui pool transport ini dengan sangat cepat dan keseluruhan perputarannya hingga 10-15 kali setiap hari, kira-kira setiap 2 jam.

Menurut helat penulis karean pool transpot besi yang cepat inilah yang menyebabkan jumlah $\mathrm{Fe}$ yang dikonsumsi akan mempengaruhi kejadian amenia. Semakin banyak $\mathrm{Fe}$ yang dikonsumsi tentu akan msemakin dapat mengimbangi besi yang transist melalui pool transport ini.

Pemberian FE selama kehamilan yang ditetapkan oleh WHO minimal 90 tablet. hal ini diperlukan untuk mencegah terjadinya anemia. Pada wanita tidak hamil yang sehat, konsentrasi hemoglobin rata-rata adalah 13,7 sampai $14 \mathrm{gr} / 100 \mathrm{ml}$. Dalam tiga bulan pertama kehamilan, konsentrasi hemoglobin 
menurun sekitar $0,5 \mathrm{gr} / 100 \mathrm{ml}$. Konsentrasi minimum dicapai pada sekitar minggu ke-30 sampai ke-32. Sekitar $65 \%$ zat besi didalam tubuh terdapat dalam bentuk hemoglobin. Sisa zat besi yang disimpan didalam tubuh dibagi menjadi feritin dan haemosiderin (merupakan $30 \%$ zat besi tubuh ), mioglobin $(3,5 \%)$, enzim hem $(0,5 \%)$, dan zat besi yang terikat trasperin yakni $0,1 \%$.

Kehilangan zat besi rata-rata setiap hari pada wanita yang sedang menstruasi adalah sekitar $2 \mathrm{mg}$. Selama masa kehamilan, kehilangan atau kebutuhan ini meningkat sampai 3-4 mg/hari akibat kebutuhan janin. Suplai diet zat besi rata-rata pada orang barat adalah 15-20 mg, 5-30\% nya diabsorbsi. Asupan zat besi dikonsumsi tidak memenuhi kebutuhan harian dalam masa kehamilan. Oleh karena itu, biasanya harus ditambah dengan mengkonsumsi medikasi oral.

Janin membutuhkan zat besi untuk mesintesis hemoglobin janin sehingga 1 gr zat besi tambahan dibutuhkan selama masa kehamilan. Hal ini menyebabkan cadangan zat besi ibu menurun. Kebutuhan janin yang lain ialah folat, yang digunakn untuk mesintesis asam nukleat.

Asupan zat besi selama masa kehamilan juga mempengaruhi upaya mempertahankan volume sel darah merah yang adekuat. Janin secara total bergantung ibu dalam mengekstrasi kebutuhan nutrisinya.

Kebutuhan total zat besi pada kehamilan berkisar antara 580-1340 mg, dan 440-1050 mg, di antaranya akan hilang dalam tubuh ibu pada saat melahirkan (Hilman, 1996).

Untuk mengatasi kehilangan ini, ibu hamil memerlukan rata-rata 3,5-4 mg zat besi per hari. Kebutuhan ini akan meningkat secara signifikan dalam trimester terakhir, yaitu dari rata-rata $2,5 \mathrm{mg} /$ hari pada awal kehamilan menjadi 6,6 mg/hari (Letsky \& Warwick, 1994). Zat besi yang tersedia dalam makanan berkisar dari 0,9 hingga 1,8 $\mathrm{mg} /$ haridan ketersedian ini bergantung pada kecukupan dietnya. Karena itu, pemenuhan kebutuhan pada kehamilan memerlukan mobilisasi simpanan zat besi dan peningkatan absorpsi zat besi. Meskipun absorpsi zat besi meningkat cukup besar selama kehamilan (Barrett et al, 1994), namun bila kehamilan yang satu dengan lainnya memiliki jarak yang cukup dekat dan/atau bila simpanan zat besinya rendah, maka asupan zat besi yang cukup hanya dapat dipenuhi lewat suplementasi. Suplemen $30 \mathrm{mg}$ zat besi/hari sudah cukup bagi sebagian besar wanita (Van Way, 1999).

Penambahan zat besi selama kehamilan sangat penting untuk diberikan kepada ibu. 90 tablet yang dianjurkan oleh WHO untuk diberikan kepada ibu selama hamil tentu dengan kondisi kesehatan ibu yang sehat sebelum hamil. Peningkatan jumlah Fe yang harus diberikan ini tentu sejalan dengan keadaan ibu. Selain itu sifat Fe yang gampang rusak dan resopsi banyak, mengharuskan ibu selama hamil untuk mengkosumsi Fe sesuai dengan kebutuhan.

\section{Hubungan Mulai Mengkonsumsi Fe dengan Kejadian Anemia}

Penelitian ini menujukan tidak terdapat hubungan antara waktu mulai konsumsi fe dengan kejadain anemia dalam kehamilan. Hal ini dibuktikan dengan didapatkannya nilai $p=0,68 .(p=, 0,05)$

Bila bukan karena perdarahan, anemia defisiensi besi adalah hasil akhir dari keseimbangan besi negatif dalam waktu yang lama. Bila total besi tubuh turun, terjadi beberapa kejadian yang mengikutinya. Pertama, simpanan besi pada hepatosit dan makrofag pada hati, limpa dan sumsum tulang berkurang. Setelah simpanan besi habis, besi plasma enurun,sehingga suplai besi pada sumsum tulang untuk pembentukan hemoglobin menjadi tidak adekuat. Sebagai akibatnya jumlah eritrosit protoporfirin bebas meningkat. Terjadilah produksi eritrosit yang mikrositik dan nilai hemoglobin turun.

Perjalanan defisiensi besi ini melalui tiga tahapan. Padatahap awal simpanan besi 
berkurang, tetapi belum mengurangi besi serum. Tahap ini diketahui dengan adanya nilai feritin yang rendah. Tahap kedua jika simpanan besi sudah habis tetapi nilai hemoglobin masih dalam batas normal. Terjadi penurunan saturasi transferin, peningkatan total iron bindind capacity (TIBC) dan peningkatan protoporfirin eritrositbebas. Nilai mean corpuscular volume (MCV) masih dalam batas normal, tetapi pada apus darah tepi sudah mulai terlihat adanya sel-sel yang mikrositik. Banyak pasien yang mulai mengeluh cepat lelah walaupun mereka belum menderita anemia. Pada tahap ketiga nilai hemoglobin turun dan terjadilah anemia defisiensi besi.

Dalam kehamilan selain proses hemodilusi tidak dimulai semenjal awal kehamilan, tetapi setelah kehamilan memasuki trimester ke dua, kalau proses hemodilusi belum terjadi, maka untuk terjadinya anemia pada ibu yang sebelum hamil dengan dengan $\mathrm{Hb}$ normal tentu tidak akan berpengaruh secara cepat. Selain itu Fe di konsumsi dengan tujuan untuk meningkatkan kadar haemoglobin yang turun akibat terjadinya hemodilusi, jadi penulis berkesimpulan bahwa untuk mencegah anemia pada ibu hamil diperlukan konsumsi Fe selama proses hemodilusi yang terjadi dalam kehamilan, pemilirian ini didasari oleh proses besi transit melalui pool transport yang sangat cepat dan keseluruhan perputarannya hingga 10-15 kali setiap hari, kira-kira setiap 2 jam. Namun demikian pendapat ini masih memerlukan penelitian lebih lanjut. Sehingga dapat membuktikan asumsi penulis ini. Dalam enam minggu pertama kehamilan, volume plasma, sel darah merah dan sirkulasi darah total dapat dibandingkan dengan volume pada wanita normal yang tidak hamil. Pada sekitar minggu ke-8 gestasi, volume plasma meningkat secara terus menerus dan pada minggu ke-20, peningkatannya mencapai 21 $\%$. Dengan kata lain, akibatnya terjadi suatu hemodilusi karena volume sel darah merah tidak meningkat ke derajat yang bermakna.
Sampai periode ini, volume tersebut berada pada tingkat yang sama dengan volume pada wanita tidak hamil, yakni $26-27 \mathrm{ml} / \mathrm{kg}$. Setelah minggu ke-24 kehamilan, volume plasma maternal stabil sampai sekitar 67-68 $\mathrm{ml} / \mathrm{kg}$ dan cukup konstan sepanjang sisa masa kehamilan. Volume sel darah merah juga tetap konstan, yakni $27 \mathrm{ml} / \mathrm{kg}$. Volume plasma total meningkat sebesar kurang lebih $50 \%$ dan sel darah merah total meningkat sekitar $20 \%$ pada periode gestasi.

\section{Hubungan Waktu Minim Fe degan kejadian Anemia.}

Waktu minum Fe ternyata tidak ada hubungannya dengan kejadian amenia pada ibu hamil. Hal ini dibuktikan dengan ditemukannya nilai $\mathrm{p}=0,68(\mathrm{p}=<0,05)$

Pada ibu hamil minum Fe di anjurkan pada malam hari, hal ini disebabka karena Fe akan menyebabkan timbulnya ransangan rasa mual. Rasa Mual ini akan semakin meningkat terutama bila usia kehamilan kurang dari 14 minggu yang diseababkan karena peningkatan Hormon HCG dalam kehamilan. Selain itu, seperti halnya kalsium, penyerapan $\mathrm{Fe}$ oleh tubuh juga menngkat pada malam hari.

Dari hasil penelitian ini tidak ditemukan adanya hubungan antara waktu minum Fe dengan kejadian anemia pada ibu hamil. Hal ini mungkin disebabkan oleh beberapa faktor diantaranya adalah karena metoda dalam penelitian ini adalah secara cross sectional, sehingga data yang diambil tentang waktu minum $\mathrm{Fe}$ adalah berdasarkan pengakuan ibu, sehingga memungkinkan terjadinya kesalahan informasi. Selain itu besarnya sample yang meminum $\mathrm{Fe}$ pada malam hari dan pagi hari tidak seimbang

Selain itu Anemia dalam kehamilan lebih disebabkan karena factor hemodilusi, Apabila tidak terjadi proses hemodilusi, yang ditandai oleh kadar hb yang tinggi dapat diindikasikan adanya gangguan pada perubahan fisiologis akibat tergangguanya sirkulasi darah plasenta yang dapat mengakibatkan gangguan pertumbuhan janin (Villard an Bergsjo 1997, 
Hemminski dan Merilainen 1995, Us Department of Health And Human scienses 1990 dalam Sweetforeward 1997) .

Hemodilusi juga mempunyai manfaat untuk ibu, pertama : pengenceran itu meringankan beban jantung yang seharusnya bekerja lebih berat dalam masa kehamilan tetapi karena adanya hidremia, cardiac output meningkat dan viskositas darah rendah sehingga resistensi perifer berkurang pula sehingga tekanan darah tidak naik, kedua : pada perdarahan waktu persalinan, banyaknya unsur besi yang hilang leabih sedikit dibandingkan dengan apabila darah itu tetap kental (Wiknjosastro , 2001)

\section{Hubungan Rutinitas konsumsi Fe dengan Kejadian Anemia}

Hipotesa awal dierkiraka ada hubungan antara rutinitas konsumsi Fe dengan kejaidan anemia, Namun hal dimentahkan dengan ditemukannya hasil statistic dengan nilai $\mathrm{p}$ $=0.98(\mathrm{p}=<0,05)$. Hasil in tidak sesuai dengan hipotesa awal yang menduga adanya hubungan antara kejadian amenia dengan rutinitas minum $\mathrm{Fe}$.

Konsumsi Fe ibu hamil di tentukan dengan mengukur kebutuhan $\mathrm{Fe}$ ibu hamil dalam tiap harinya, Volume darah yang berfungsi mendorong metabolisme sinergis pada organ tubuh ibu, fetus dan di gunakan dalam sirkulasi plasenta bertambah banyak (Hidremia/Hipervolumia) hingga mencapai 50\% (Bennet dan Brown, 1996) . Akan tetapi pertambah sel-sel darah tidak sebanding dengan bertambahnya plasma sehingga terjadi pengenceran darah yang di sebut dengan hemodilusi atau peningkatan volume plasma. pertambahan tersebut berbanding sebagai berikut : Plasma $30 \%$, sel darah $18 \%$ dan $\mathrm{Hb}$ 19\% (Wiknjosastro, 2001)

Selama hamil kebutuhan gizi meningkat di bandingkan dengan kebutuhan sebelum hamil misalnya kebutuhan protein meningkat $68 \%$, asam folat $100 \%$ kalsium $50 \%$ dan zat besi $200-300 \%$.
Keadaan serum nutrien pada ibu hamil dan wanita tidak hamil

\begin{tabular}{|l|l|l|}
\hline Nutrien & $\begin{array}{l}\text { Normal wanita } \\
\text { tidak hamil }\end{array}$ & $\begin{array}{l}\text { Wanita } \\
\text { hamil }\end{array}$ \\
\hline Total protein & $6.5-8.5 \mathrm{~g} / 100 \mathrm{ml}$ & $60-8.0$ \\
\hline Albumin & $3.5-5.0 \mathrm{~g} / \mathrm{ml}$ & $3.0-4.5$ \\
\hline Glukosa & $<110 \mathrm{mg} / 100 \mathrm{ml}$ & $<120$ \\
\hline Kolesterol & $\begin{array}{l}120-190 \\
\mathrm{mg} / 100 \mathrm{ml}\end{array}$ & $200-325$ \\
\hline Vitamin A & $20-60 \mu / 100 \mathrm{ml}$ & $20-60$ \\
\hline Asam askorbik & $\begin{array}{l}0.2-2.0 \\
\mathrm{mg} / 100 \mathrm{ml}\end{array}$ & $0.2-1.5$ \\
\hline Asam folat & $5-21 \mathrm{ng} / 100 \mathrm{ml}$ & $3-15$ \\
\hline Kalsium & $4.6-5.5 \mathrm{mEq} / \mathrm{L}$ & $4.2-5.2$ \\
\hline Besi & $>50$ & $>40$ \\
\hline Iron building capacity & $\begin{array}{l}250-400 \\
\mu \mathrm{g} / 100 \mathrm{ml}\end{array}$ & $300-450$ \\
\hline ( Sumber : Bonnie S Worthington-Roberts, \\
1989)
\end{tabular}

Dengan demikian, kebutuhan total zat besi pada kehamilan berkisar antara 580$1340 \mathrm{mg}$, dan 440-1050 mg, di antaranya akan hilang dalam tubuh ibu pada saat melahirkan (Hilman, 1996). Zat besi yang tersedia dalam makanan berkisar dari 0,9 hingga $1,8 \mathrm{mg} /$ haridan ketersedian ini bergantung pada kecukupan dietnya. Karena itu, pemenuhan kebutuhan pada kehamilan memerlukan mobilisasi simpanan zat besi dan peningkatan absorpsi zat besi. Meskipun absorpsi zat besi meningkat cukup besar selama kehamilan (Barrett et al, 1994), namun bila kehamilan yang satu dengan lainnya memiliki jarak yang cukup dekat dan/atau bila simpanan zat besinya rendah, maka asupan zat besi yang cukup hanya dapat dipenuhi lewat suplementasi. Suplemen $30 \mathrm{mg}$ zat besi/hari sudah cukup bagi sebagian besar wanita (Van Way,1999).

Dalam penelitian ini asupan zat besi dari makanan tidak dikaji, sehingga memungkinkan meskipun ibu tidak mengkonsumsi $\mathrm{Fe}$ dalam bentuk suplemen pada hari yang sama si ibu mengkonsumsi makanan yang cukup mengandung Fe maka kebutuhan ibu terhadap Fe tetap terpenuhi. 


\section{SIMPULAN}

\begin{abstract}
Berdasarkan hasil penelitian pada bab sebelumnya penulis dapat menarik kesimpulan bahwa ibu hamil yang mengkosumsi $\mathrm{Fe}$ minimal 90 tablet masih rendah sehingga kejadian anemia yang ditemkanpun masih tinggi yaitu sebanyak $44,1 \%$.
\end{abstract}

Pada penelitian ini ditemukan hubungan yang bemakna antara jumlah konsumsi Fe pada ibu hami degan kejadian Anemia dalam kehamilan. Sedangkan pada tiga vaiabel lainnya yaitu ritnitas mengkonsumsi $\mathrm{Fe}$ setiap harinya, waktu mengkonsumsi Fe dan usia kehamilan pada saat memulai konsumsi Fe tidak ditemukan hubungan dengan kejadian anemia dalam kehamilan. Ibu hamil yang megkonsumsi $\mathrm{Fe}$ minimal 90 tablet selama kehamilan akan dapat menurunkan angka kejadian anemia. Oleh sebab itu perlu bagi bidan untuk mengupayakan pemantauan konsusi $\mathrm{Fe}$ tang telah diberika keada ibu selama kehamilan.

\section{DAFTAR PUSTAKA}

Ahmad N, Kalakoti P, Bano R, Aarif SM. 2010. The prevalence of anaemia and associated factors in pregnant women in rural Indian community. Med J Aust.

Alleyne M, Horne MK, Miller JL. 2008. Individual pengobatan untuk anemia defisiensi zat besi pada orang dewasa. Am J Med.

Anemia.

http://ninp.rumwahyuni.wordpress.com (diakses 8 juni 2013).

Bakta IM. 2011.Pendekatan terhadap pasien anemia. In: Sudoyo AW, Setiyohadi B, Alwi I, Simadibrata M, Setiati S, penyunting. Buku Ajar Ilmu Penyakit Dalam (5th ed). Jakarta Pusat: Interna Publishing Cunningham, F.G, dkk. 2006. ObstetriWilliams. Vol. l. ed. 21. Jakarta:Penerbit Buku Kedokteran EGC.
Bobak, LM., Lowdermik, D.L., \&Jensen,M.D. 2005. Buku Ajar Keperawatan Maternitas. ed. 4. Jakarta : Penerbit Buku Kedokteran EGC Departemen Kesehatan Republik Indonesia. 2008. Profil KesehatanIndonesia 2008. http://www.depkesgo.id (diakses tangga101 Mare

Brown, J.E. et.al. (2002). Nutrition Trought the Life Cycle, International Student Edition, 3rd, Thomson Wardsworth.

Elsy N. 2012.Faktor-faktor yang berhubungan dengan kejadian anemia pada ibu hamil trimester III di wilayah kerja puskesmas air dingin kota Padang tahun 2012 [Skripsi]. Padang: Fakultas Kedokteran Universitas Andalas;

Florencia T. P . Suparman Eddy.Hermie M. M Profil Zat Besi (Fe) Pada Ibu Hamil Dengan Anemia Di Puskesmas Bahu Manado Jurnal E-Clinic (Ecl), Volume 4, Nomor 1, Januari-Juni 2016

Hinderaker SG, Olsen BE, Lie RT, et al. 2002Anemia in pregnancy in rural Tanzania: associations with micronutrients status and infections. Eur $\mathrm{J}$ Clin Nutr.

Khomsan, A. 2004. Pangan dan Gizi Untuk Kesehatan. Jakarta: PT Raja Grafindo Persada.

Klein, S., \& Thomson, F. 2008. Panduan Lengkap Kebidanan. Yogyakarta Mitra Setia

Kurnar, V., Cotran, R.S., \& Robbins, S.L. 2007. Buku ajar Patologi Robbins.Vol. 2, ed. 7. Jakarta: Penerbit Buku Kedokteran EGC.

Llwellyn-Jones, D. 2002. Dasar-Dasar Obstetri \& Ginekologi, ed. 6.Jakarta: Hipokrates.

Madhavi LH, Singh HKG. 2011.Nutritional status of rural pregnant woman. People's J Sci Res.

Mirzaie F, at All. 2010. Prevalence of anemia risk factors in pregnant women in Kerman, Iran. Iran J Reprod Med. 
Nurhayati1, Halimatusakdiah2, Asniah3 Pengaruh Asupan Tablet Zat Besi (Fe) Terhadap Kadar Haemoglobin (Hb) Pada Ibu Hamil Di Puskesmas Kopelma Darussalam Tahun 2014 .Idea Nursing Journal Vol. Vi No. 3

Notoatmodjo, S. 2002. Metodologi Penelitian Kesehatan. Jakarta:Rineka Cipta.

Pipit S. 2014.Gambaran sikap ibu hamil tentang perawatan payudara selama hamil di pos kesehatan desa Pundungrejo Tawangsari Sukoharjo tahun 2013. Jurnal Kebidanan Indonesia.
Sudha R, Suryaprabha ML. 2013 Prevalence of anaemia and factors influencing anaemia in adolscent girls in urban and rural area of a South Indian city. Int $\mathrm{J}$ Pharm Bio Sci.

Siamintarsih, D. 2000. Faktor-Faktor yangBerhubungan Dengan Konsumsi Tablet Besi (Fe) Ibu Hamil diPuskesmas Kendal II Kabupaten Kendal.

WHO. The prevalence of anaemia in 2011. WHO global database on anaemia geneva. World health organization 